\title{
The Relationship between Social Support and Assertiveness among U niversity Students
}

\section{Ahmed K. A. Younes (Ph.D.)}

Assistant Professor Social Casework Department Faculty of Social Work, Helwan University, Egypt 
The Egyptian Journal of Social Work (EJSW) https://ejsw.journals.ekb.eg/e ISSN: 2356-9204 Vol 11, Issue.1, January2021 
The Egyptian Journal of Social Work (EJSW) https://ejsw.journals.ekb.eg/e

ISSN: 2356-9204

Vol 11, Issue.1, January2021

\section{Abstract}

This study aimed to determine the relationship between social support and assertiveness among university students. It helps the caseworker understand the conditions and factors that affect the development of assertiveness or achieving social support among clients. It adopted the analytical descriptive method. It applied the social support questionnaire and the assertiveness scale to a randomly selected sample of (360) university students: (190) males and (170) females. The results showed that there is a statistically significant positive relationship at the level of 0.01 between social support and its domains (support from the family, support from colleagues and friends, and support from the university) and assertiveness among university students. Gender (male or female) and the type of study (scientific or humanities) affect this relationship. The study recommends consolidating the examination of the relationship between social support and assertiveness across various cultures, as well as the impact of the demographic and academic characteristics of students on this relationship.

Keywords: Social support, assertiveness, support from the family, support Introduction

from colleagues and friends, support from the university.

The social environment plays a vital role in determining the patterns of behavior and the formation of personality. None can live alone without belonging to a trusted group that gives support in all life situations. The first group is the family in which a person learns values, social habits, and behaviors that form the personality in childhood and later life stages. By joining the school, university, and work and interacting with others, human behavior is formed. The more appropriate social support is given, the better the person grows psychologically and socially and builds an assertive personality that enjoys self-confidence, high self-esteem, freedom of expression, and mutual respect. However, a person always encounters increasing difficulties through various life stages. University is the most important period in which students experience difficulties and challenges that require positive personal skills and social support resources.

According to Ali (2000), Almajali (2017), Al-Sharqawi (2007), Bashir (2016), Halasa (2016), Muhammad (2003), and Rashwan (2007), social support and assertiveness are the main goals that a caseworker seeks to achieve in clients' personality and environments. Because of the importance of these two variables, 
authors have designed professional intervention programs to enhance social support and assertiveness among university students as these variables help with developing personalities, improving communication skills and social interaction, achieving personal and social competence, developing problem-solving skills, coping with stress, creating personal and emotional compatibility, and improving leadership skills and academic performance.

Studies indicated the predictive significance of social support and assertiveness. According to Akeren and Ay (2019), the perceived social support and assertiveness are significant predictors of the need for psychological help among university students. Moreover, Parmaksiz (2019) indicated that the university students' assertiveness total scores predicted their adjustment to university, emotional adjustment, personal adjustment, adjustment to the opposite sex, social adjustment, academic adjustment, and total adjustment scores. Reviewing the literature shows the considerable importance and the positive role of assertiveness and social support in the lives of university students.

\section{Social Support}

Hammouda and Rasheed (2011) found that social support enhances the personal and social compatibility of university students. Abo Elela (2012) and Ali (2000) found a positive relationship between social support, on one hand, and stress coping strategy and psychological compatibility, on the other, among university students. In contrast, Al-Mahdawi (2010) showed a negative relationship between social support and some psychiatric disorders, such as anxiety and depression.

Eskin (1995) reported that previous suicide attempts among the adolescents relate to the low perceived family support, perceived peer support, and assertiveness skills. Fayed (2006) concluded that social support plays an important role in reducing stress and suicidal thoughts among university students. Al-Tom (2018) also found that the high level of social support has a positive impact on university students in preventing drugs. Al-Issawi, Suleiman, and Ibrahim (2017), Hussein and Abbas (2014), and Najjar and Abo Darweesh (2011) highlighted the positive relationship between social support, self-esteem, and academic achievement. Ismail (2010) highlighted the relationship between social support and the quality of life among university students. Lashari, Kaur, and Awang-Hashim (2018) revealed that social support is associated with greater academic and psychological adjustment among international students. 
The Egyptian Journal of Social Work (EJSW) https://ejsw.journals.ekb.eg/e

ISSN: $2356-9204$

Vol 11, Issue.1, January2021

\section{Assertiveness}

According to Al-Amoudi (2001), Al-Dafai (2011), Badari and Al-Shennawi (1987), Bani Younes (2005), Bayrami(2011), and De Miguelsanz, Martin, and Martinez (2012), assertiveness has a positive relationship with emotional balance, internal control, academic performance, social skills and success of social relations, psychological and social compatibility among university students. Lee and Ciftci (2014) indicated that assertiveness is associated with sociocultural adaptation mediated by academic self-efficacy. Moreover, Ahmed (2012), Al-Ahmad (2018), Alotayan (2017), Gad (2014), and Kwassa and Muhammad (2000) illustrated that assertiveness has a positive relationship with the style of democratic treatment, parental acceptance, warmth, and love and has a negative relation with the negligence and parental rejection. Al-Mahdawi (2010) and AlMusharraf (2002) also found a negative relationship between anxiety, depression, and assertiveness. Khalil (2014) reported a negative relationship between stress and assertiveness.

\section{Social Support and Assertiveness}

Assertiveness is related to the skill of establishing successful social relationships. It also allows a person to request a service from others, help them with social support, and participate in social activities Hussein and Hussein (2006). In contrast, a person may not be able to apply assertiveness correctly which affects the social relations and support received from others. Therefore, assertiveness falls between withdrawing and aggressive behavior (Baza, 2003).

Kukulu et al. (2006) examined the interrelations between social support from colleagues, friends, and family and communication skills, on one hand and their interrelations to assertiveness, on the other, using a path model. The results showed that there was a somewhat indirect relationship between the perceived social support from colleagues, friends, and communication skills. Furthermore, there was no direct or indirect relationship between perceived family support and assertiveness.

Some studies, such as Ali (2018), Al-Shahrani (2012), Elliott (1991), Monti (2002), and Segal (2005), tackled the relationship between social support and assertiveness. They examined different samples that are not directly related to university students.

Therefore, defining the direction and strength of the relationship between social support and assertiveness should be studied, especially in the Arab environment. Several studies, including Al-Tarawneh and Al-Subhiyin (2015), Mokhaimar (2015), and 
The Egyptian Journal of Social Work (EJSW) https://ejsw.journals.ekb.eg/e

ISSN: 2356-9204

Vol 11, Issue.1, January2021

Raishan (2008), explored these variables separately to identify their availability among university students or their relationship to other variables without considering their interrelationship.

\section{Statement of the Problem}

Based on the review of the relevant several previous studies on the relationship between two significant variables in the work of the caseworker, the present study investigates the direction and strength of the relationship between social support and assertiveness among university students.

\section{Research Questions}

The first main question: Is there a relationship between the levels of social support and assertiveness among university students? What is the type of relationship? Does this relationship differ according to gender and the type of study?

This question is sub-divided into minor ones:

- Is there a relationship between the levels of social support from the family and assertiveness among university students? What is the type of relationship?

- Is there a relationship between the levels of social support from the university and assertiveness among university students? What is the type of relationship?

- Is there a relationship between the levels of social support from friends and colleagues and assertiveness among university students? What is the type of relationship?

The second main question: Are there differences in the level of social support due to social gender or the type of study?

The third main question: Are there differences in the level of assertiveness due to social gender or the type of study?

\section{Study Significance}

Theoretical significance

The study is significant in terms of the targeted group and topic. It covers university students who are responsible for leading society and achieving development. Society pays special attention to this group by allocating funding for universities and creating job opportunities for university students who should demonstrative assertive qualities. Moreover, achieving social support and knowing its impact on assertiveness among university students is important.

Applied significance

The study is significant because identifying the availability, type, and strength of the relationship between social support and assertiveness is useful in the applications of assistance and 
The Egyptian Journal of Social Work (EJSW) https://ejsw.journals.ekb.eg/e

ISSN: 2356-9204

Vol 11, Issue.1, January2021

professional intervention among university students who need psychological and social support.

\section{Objectives}

The study aims to:

- Define the relationship between social support and assertiveness among university students through the relationship between social support domains (from the family, university, as well as colleagues and friends) and assertiveness.

- Define the relationship between social support and its domains (from the family, university, as well as colleagues and friends) and the personal and academic variables of (gender and type of study) among university students.

- Define the relationship between assertiveness and personal and academic variables of (gender and type of study) among university students.

\section{Study Concepts}

Social support is "the emotional, material, and performance support that the individual receives from family, friends, colleagues, and business leaders allowing him/her to interact with stress events" (Ali,2000, p.6), "have deep social relationships with individuals who give advice and guidance and accept this support" (Al-Sarsi and Abdel-Maqsoud, 2014, p.5; Saleh, 2009, p.20). The author defines it as the university students' feeling of being appreciated, respected, interested, and accepted by others, as well as and providing them with information or assistance in performing their academic duties). This support includes:

Support from the family that means support from the family members, e.g., the parents, brothers and daughters, and relatives.

Support from colleagues and friends that means support from colleagues and friends in the local and university environments.

Support from the university that means support from the faculty members, academic adviser, and staff of the college and the university with whom the student deals with in university life.

Social support is procedurally defined as the degree obtained by the participants on the social support questionnaire for university students, which is divided into three domains: Support from the family, support form colleagues and friends, and support from the university.

Assertiveness is "the individual's skill in expressing various opinions and positive (praise) or negative (anger) feelings, defending their own rights and continuing to end social interactions, and 
resisting the stress from others" (Farag, 2003, p.109). It is an aspect of personality that shows association with success or failure in social relationships (Ibrahim, 2001). It is also known as a multi-domain behavior that reflects social skills, such as the defense of rights, social assertiveness, and guiding. Moreover, it is "a set of positive and negative, verbal and nonverbal behavior patterns in which the individual responds to others, such as peers, parents, and siblings in interpersonal interactions" (Abdel-Rahman, 1998, p.154). According to Baza (2003, p.2), it is "a set of positive responses that demonstrate the ability to freely express emotions, opinions, rights, friendly and emotional feelings; give orders and control behaviors; demonstrate self-control, self-confidence, challenge, and commitment".

Assertiveness is the "behavior that enables a person to meet interests, defend the self, and freely express sincere feelings and personal rights without denying the rights of others" (Ghareeb, 1995, p.5). The author defines it as the behavior through which a university student can obtain rights and freely express feelings towards others. It is procedurally defined as is the degree that the participant obtains on the assertiveness scale for adolescents and youth developed by Baza (2003).

\section{Methodology}

\section{Study design}

The present study belongs to the analytical descriptive studies and depends on the quantitative approach to determine the characteristics of phenomena and the relationship between the variables, such as the relationship between the social support and assertiveness among university students.

\section{Hypotheses}

The first main hypothesis: There is a statistically significant positive relationship between social support and assertiveness.

Minor hypotheses:

- There is a statistically significant relationship between social support from the family and assertiveness.

- There is a statistically significant relationship between social support from friends and colleagues and assertiveness.

- There is a statistically significant relationship between social support from the university and assertiveness.

The second main hypothesis: There is a statistically significant relationship between assertiveness and some personal and academic variables. 
The Egyptian Journal of Social Work (EJSW) https://ejsw.journals.ekb.eg/e

ISSN: 2356-9204

Vol 11, Issue.1, January2021

Minor hypotheses:

- There is a statistically significant relationship between assertiveness and gender (male-female).

- There is a statistically significant relationship between assertiveness and the type of study (scientific-humanities).

The third main hypothesis: There is a statistically significant relationship between social support and some personal and academic variables.

Minor hypotheses:

- There is a statistically significant relationship between social support and gender (male-female).

- There is a statistically significant relationship between social support and the type of study (scientific-humanities).

The fourth main hypothesis: The relationship between social support, assertiveness, and some personal and academic variables is affected among university students.

Minor hypotheses

- The relationship between social support and assertiveness varies according to gender (male-female).

- The relationship between social support and assertiveness Tools varies according to the type of study (scientific-humanities).

The author utilized two basic tools to measure the research variables:

- The social support questionnaire for university students developed by the author.

- The assertiveness scale for adolescents and youth developed by Baza (2003).

First: Social support questionnaire for university students

The author reviewed the theoretical framework and relevant literature on social support and a set of social support scales, namely the social support scale for adolescents and youth (Al-Sarsi and Abdel-Maqsoud, 2014), the social support scale for $1^{\text {st }}$-grade secondary students (Daniel, 2008 a), the social support scale (Daniel, 2008 b), and the social support scale for industrial workers (Ismail, 2004). The questionnaire comprised three domains (Table 1), i.e., support from the family (10 items), support from friends and colleagues (10 items), and support from the university (12 items). Then, the author formulated a set of positive and negative items in each domain. 


\begin{tabular}{||cr||}
\hline \multicolumn{2}{|c||}{ The Egyptian Journal of Social Work (EJSW) https://ejsw.journals.ekb.eg/e } \\
ISSN: $2356-9204$ & Vol 11, Issue.1, January2021 \\
\hline
\end{tabular}

Table (1): Domains and items of the social support questionnaire

\begin{tabular}{|l|l|l|}
\hline \multicolumn{1}{|c|}{ Domain } & \multicolumn{1}{|c|}{ Positive items } & \multicolumn{1}{|c|}{$\begin{array}{c}\text { Negative } \\
\text { items }\end{array}$} \\
\hline Support from the family & $1-5-10-15-17-25-27-30$ & $20-34$ \\
\hline Support from friends and colleagues & $3-7-12-14-18-24-28-29-32$ & 22 \\
\hline Support from the university & $\begin{array}{l}2-4-6-9-11-13-16-19-23-26- \\
\text { 31-33 }\end{array}$ & \\
\hline
\end{tabular}

- Validity and reliability of the social support questionnaire: Content validity: The questionnaire was presented to two academics specialized in social work and psychology to express their opinions on items' phrasing.

Internal consistency: The correlation coefficient between the score of each domain of the questionnaire and the total score on a sample of 55 participants was calculated, as shown in Table (2).

Table (2): The score of correlation and the total score of the questionnaire

\begin{tabular}{|l|l|}
\hline Domain & Total \\
\hline Support from the family & $.734^{* *}$ \\
\hline Support from colleagues and friends & $.850^{* *}$ \\
\hline Support from the university & $.820^{* *}$ \\
\hline
\end{tabular}

-Reliability of the social support questionnaire: To calculate the reliability of the questionnaire, the author relied on Cronbach's alpha and the split-half method using the Spearman-Brown Formula by applying to a sample of 55 participants, as shown in Table (3).

Table (3): The reliability of the questionnaire

\begin{tabular}{|l|l|l|l|}
\hline Domain & $\begin{array}{l}\text { No. } \\
\text { items }\end{array}$ & Cronbach's Alpha & Correlation \\
\hline Support from the family & 10 & .834 & 0.734 \\
\hline Support from colleagues and friends & 10 & .724 & 0.737 \\
\hline Support from the university & 12 & .744 & 0.792 \\
\hline Questionnaire & 32 & .852 & 0.765 \\
\hline
\end{tabular}

Table (2) and (3) illustrate the high degree of validity and reliability of the questionnaire. Thus, it can be applied in the research. - Rating the scales: The questionnaire comprised 32 items: Always (4), sometimes (3), rarely (2), and never (1) for the positive items and vice versa for the negative ones.

Table (4) shows the maximum score for each domain and the questionnaire, as well as dividing social support into three categories. 


\begin{tabular}{||cr||}
\hline The Egyptian Journal of Social Work (EJSW) https://ejsw.journals.ekb.eg/e \\
ISSN: $2356-9204$ & Vol 11, Issue.1, January2021 \\
\hline
\end{tabular}

Table (4): The scores of the social support questionnaire

\begin{tabular}{|c|c|c|c|c|c|c|c|c|}
\hline \multirow{2}{*}{ Domain } & \multirow{2}{*}{$\begin{array}{l}\text { No. } \\
\text { items }\end{array}$} & \multirow{2}{*}{$\begin{array}{l}\text { Maximum } \\
\text { score }\end{array}$} & \multirow{2}{*}{$\begin{array}{l}\text { Minimum } \\
\text { score }\end{array}$} & \multirow{2}{*}{ Average } & \multirow{2}{*}{$\begin{array}{l}\text { Class } \\
\text { length }\end{array}$} & \multicolumn{3}{|c|}{ Interpretation of the score } \\
\hline & & & & & & $\begin{array}{c}\text { Weak } \\
\text { support }\end{array}$ & $\begin{array}{c}\text { Moderate } \\
\text { support }\end{array}$ & $\begin{array}{c}\text { High } \\
\text { support }\end{array}$ \\
\hline $\begin{array}{c}\text { Support from } \\
\text { the family }\end{array}$ & 10 & 40 & 10 & 30 & 10 & $10-20$ & 21-30 & $31-40$ \\
\hline $\begin{array}{c}\text { Support from } \\
\text { colleagues and } \\
\text { friends }\end{array}$ & 10 & 40 & 10 & 30 & 10 & $10-20$ & 21-30 & $31-40$ \\
\hline $\begin{array}{l}\text { Support from } \\
\text { the university }\end{array}$ & 12 & 48 & 12 & 36 & 12 & $12-24$ & $25-36$ & $37-48$ \\
\hline Total & 32 & 128 & 32 & 96 & 32 & $32-64$ & $65-96$ & $97-128$ \\
\hline
\end{tabular}

Second: Assertiveness Scale for adolescents and youth

Baza (2003) developed the assertiveness scale for adolescents and youth, which comprised 26 items. The reliability of the scale was calculated by test-retest and scored (0.87). The validity was calculated using the self-affirmation test developed by Ghareeb (1995) that scored (0.85) and (0.83) for the males and females, respectively.

- Validity and reliability of the assertiveness scale: The

author re-tested the validity and reliability of the scale to ensure its validity for application in this research on a sample of (55) participants.

Discriminatory validity (peripheral comparison): The author calculated the discriminatory validity by comparing the highest and lowest groups' scores. Each group comprised (15) participants (27\% of the sample), as shown in table (5).

Table (5): The value of " $T$ " for the two independent groups and its significance

\begin{tabular}{|l|l|l|l|l|l|}
\hline Groups & No. & Means & SD & T & Sig \\
\hline The highest scores & 15 & 22.2 & .77 & 43.284 & 0.01 \\
\cline { 1 - 4 } The lowest scores & 15 & 9.1 & .88 & & \\
\hline
\end{tabular}

The reliability of the assertiveness scale was estimated by calculating Cronbach's alpha that scored (0.869) and using the splithalf method. The correlation value between the two halves of the scale using the Spearman-Brown Formula was (0.93).

- Rating the scales: If the choice expresses the presence of assertiveness, the participant gets a score. If it does not express, the participant gets zero. A high score indicates a high assertiveness, while a low score indicates a low assertiveness. The maximum score for the scale is 26 , and the minimum is zero. The scores are classified into three categories: Low assertiveness (from 0 to 8.67), moderate assertiveness (from 8.68 to 17.34 ), and high assertiveness (from 17.35 to 26). 


\begin{tabular}{|l} 
The Egyptian Journal of Social Work (EJSW) https://ejsw.journals.ekb.eg/e \\
ISSN: $2356-9204$ \\
Vol 11, Issue.1, January2021
\end{tabular}

\section{Sample}

The study was applied to a randomly selected sample of (360) students from the colleges of the main branch of Majmaah University in Saudi Arabia out of the population that comprised (5589) and the sample was calculated by applying Richard Geiger's equation for the optimal sample size. The sample comprised (190) males (52.8\%) and (170) females $(47.2 \%)$. It covered the humanities colleges, i.e., the College of Education and Business Administration with participants numbered (298) rating (82.8\%) and scientific colleges, i.e., the College of Computer and Information Sciences, College of Medicine, and College of Engineering with participants numbered (62) rating $(17.2 \%)$. Scientific colleges have a limited number of students compared to the large size of admission to the humanities colleges. The arithmetic means of students' age is (21.58) years with a standard deviation (1.9), calculating from (277) participants.

\section{Statistical processing}

The data were coded and processed. Then, the appropriate statistical methods were applied using SPSS (v26).

\section{Results}

Table (6): Descriptive statistical of the research variables

\begin{tabular}{|c|c|c|c|c|c|c|c|}
\hline Samples & Domain & Means & SD & Median & $\begin{array}{l}\text { Ske- } \\
\text { wness }\end{array}$ & $\begin{array}{l}\text { Kurt- } \\
\text { osis }\end{array}$ & Level \\
\hline \multirow[t]{5}{*}{$\begin{array}{l}\text { Sampling } \\
\mathrm{N}=\mathbf{3 6 0}\end{array}$} & $\begin{array}{l}\text { Support from the } \\
\text { family }\end{array}$ & 31.86 & 4.5 & 32 & -.261 & -.598 & High \\
\hline & $\begin{array}{lr}\begin{array}{l}\text { Support } \\
\text { colleagues } \\
\text { friends }\end{array} & \text { from } \\
\text { and } \\
\end{array}$ & 30.61 & 4.82 & 31 & -.275 & -.569 & High \\
\hline & $\begin{array}{l}\text { Support from the } \\
\text { university }\end{array}$ & 35.73 & 5.43 & 35 & -.072 & -.120 & Moderate \\
\hline & Social support & 98.2 & 12.65 & 98 & -.202 & -.499 & High \\
\hline & Assertiveness & 15.68 & 3.2 & 16 & .019 & -.362 & Moderate \\
\hline \multirow[t]{5}{*}{$\begin{array}{l}\text { Male sample } \\
\mathrm{N}=190\end{array}$} & $\begin{array}{l}\text { Support from the } \\
\text { family }\end{array}$ & 30.71 & 4.5 & 30 & .267 & -1.078 & High \\
\hline & $\begin{array}{lr}\begin{array}{l}\text { Support } \\
\text { colleagues } \\
\text { friends }\end{array} & \text { from } \\
\end{array}$ & 29 & 4.8 & 28 & .202 & -.304 & Moderate \\
\hline & $\begin{array}{l}\text { Support from the } \\
\text { university }\end{array}$ & 34.5 & 5.46 & 33 & .219 & -.327 & Moderate \\
\hline & Social support & 94.2 & 12.82 & 91.5 & .230 & -.334 & Moderate \\
\hline & Assertiveness & 15.4 & 3.22 & 15 & .114 & -.330 & Moderate \\
\hline \multirow{5}{*}{$\begin{array}{l}\text { Female } \\
\text { sample } \\
\mathrm{N}=170\end{array}$} & $\begin{array}{l}\text { Support from the } \\
\text { family }\end{array}$ & 33.15 & 4.11 & 34 & -.077 & 1.578 & High \\
\hline & $\begin{array}{lr}\begin{array}{l}\text { Support } \\
\text { colleagues } \\
\text { friends }\end{array} & \text { from } \\
\end{array}$ & 32.42 & 4.15 & 33 & -.936 & .457 & High \\
\hline & $\begin{array}{l}\text { Support from the } \\
\text { university }\end{array}$ & 37.11 & 5.07 & 38 & -.838 & -.093 & High \\
\hline & Social support & 102.69 & 10.84 & 104 & -.367 & .366 & High \\
\hline & Assertiveness & 16.01 & 3.14 & 16 & -.623 & -.309 & Moderate \\
\hline $\begin{array}{l}\text { Scientific } \\
\text { colleges }\end{array}$ & $\begin{array}{l}\text { Support from the } \\
\text { family }\end{array}$ & 34.40 & 3.82 & 35.5 & -1.390 & 2.133 & High \\
\hline
\end{tabular}




\begin{tabular}{||cr|}
\hline The Egyptian Journal of Social Work (EJSW) https://ejsw.journals.ekb.eg/e \\
ISSN: $2356-9204$ & Vol 11, Issue.1, January2021 \\
\hline
\end{tabular}

\begin{tabular}{|c|c|c|c|c|c|c|c|}
\hline \multirow[t]{4}{*}{$\mathrm{N}=62$} & $\begin{array}{lr}\begin{array}{l}\text { Support } \\
\text { colleagues }\end{array} & \text { from } \\
\text { friends } & \text { and } \\
\end{array}$ & 32.71 & 4.62 & 33 & -1.208 & 2.523 & High \\
\hline & $\begin{array}{l}\text { Support from the } \\
\text { university }\end{array}$ & 36.58 & 6 & 36 & -.508 & .176 & High \\
\hline & Social support & 103.69 & 11.66 & 105.5 & -1.138 & 2.243 & High \\
\hline & Assertiveness & 16.81 & 3.2 & 17 & -.431 & .071 & Moderate \\
\hline \multirow{5}{*}{$\begin{array}{l}\text { Humanities } \\
\text { colleges } \\
\mathrm{N}=\mathbf{2 9 8}\end{array}$} & $\begin{array}{l}\text { Support from the } \\
\text { family }\end{array}$ & 31.33 & 4.43 & 31 & .090 & -555 & High \\
\hline & $\begin{array}{lr}\begin{array}{l}\text { Support } \\
\text { colleagues }\end{array} & \text { from } \\
\text { friends } & \text { and } \\
& \end{array}$ & 30.17 & 4.76 & 30 & -.124 & -.782 & High \\
\hline & $\begin{array}{l}\text { Support from the } \\
\text { university }\end{array}$ & 35.55 & 5.33 & 35 & .024 & -.115 & Moderate \\
\hline & Social support & 97.05 & 12.56 & 96 & -.043 & $\begin{array}{l}.601 \\
\end{array}$ & High \\
\hline & Assertiveness & 15.45 & 3.15 & 15 & .101 & -.302 & Moderate \\
\hline
\end{tabular}

Table (6) illustrates that the level of the participants' perception of social support was high, and the average score was (98.2). It remained high without being influenced by personal and academic variables. Therefore, the sample of females, scientific colleges' students, and humanities colleges' students had arithmetic means of (102.69), (103.69), and (97.05), respectively. The average decreased in the sample of males with an arithmetic means of (94.2). Moreover, the sub-domains of social support were high in the sample with an arithmetic means of (31.86) and remained high without being influenced by gender or the type of study. The social support from colleagues and friends was high with an arithmetic means of (30.61) and remained high among females and students in the scientific and humanities colleges, but it decreased among the males with an arithmetic means of (29). Social support from university was lower than other domains. It was generally at the moderate level with an arithmetic means of (35.73) and remained moderate among the males and the students of humanities colleges. In contrast, it was high among the female and students of scientific colleges.

Assertiveness was ranked moderate without being influenced by the variables of gender and the type of study. In the whole sample, the arithmetic means of assertiveness was (15.81). For the samples of males, females, scientific and humanities colleges, it scored (16.01), (16.81), and (15.45), respectively. By comparing the mean and median values and reviewing the values of torsion and kurtosis, there was no standard normal distribution for the social support variable and its sub-domains, as well as the assertiveness variable. However, it approached the normal distribution. 


\begin{tabular}{||cr|}
\hline \multicolumn{2}{|c|}{ The Egyptian Journal of Social Work (EJSW) https://ejsw.journals.ekb.eg/e } \\
ISSN: $2356-9204$ & Vol 11, Issue.1, January2021 \\
\hline
\end{tabular}

Table (7): The significance of the differences in social support and assertiveness according to gender

\begin{tabular}{|c|c|c|c|c|c|c|c|}
\hline Domains & Groups & No. & Means & SD & Mean difference & $\mathrm{T}$ & Sig \\
\hline \multirow{2}{*}{ Support from the family } & Males & 190 & 30.71 & 4.5 & \multirow[t]{2}{*}{2.44} & \multirow[t]{2}{*}{5.357} & \multirow[t]{2}{*}{.000} \\
\hline & Females & 170 & 33.15 & 4.11 & & & \\
\hline \multirow{2}{*}{ Support from colleagues and friends } & Males & 190 & 29 & 4.8 & \multirow[b]{2}{*}{3.42} & \multirow[t]{2}{*}{7.229} & \multirow[t]{2}{*}{.000} \\
\hline & Females & 170 & 32.42 & 4.15 & & & \\
\hline \multirow{2}{*}{ Support from the university } & Males & 190 & 34.5 & 5.46 & \multirow[b]{2}{*}{2.61} & \multirow[t]{2}{*}{4.726} & \multirow[t]{2}{*}{.000} \\
\hline & Females & 170 & 37.11 & 5.07 & & & \\
\hline \multirow{2}{*}{ Social support } & Males & 190 & 94.2 & 12.82 & \multirow[t]{2}{*}{8.49} & \multirow[t]{2}{*}{6.768} & \multirow[t]{2}{*}{.000} \\
\hline & Females & 170 & 102.69 & 10.84 & & & \\
\hline \multirow{2}{*}{ Assertiveness } & Males & 190 & 15.4 & 3.22 & \multirow[t]{2}{*}{0.61} & \multirow[t]{2}{*}{1.870} & \multirow[t]{2}{*}{.063} \\
\hline & Females & 170 & 16.01 & 3.14 & & & \\
\hline
\end{tabular}

Table (7) shows significant differences at the level of 0.001 between males and females in social support and its subdomains, where the value of " $t$ " was (6.768) with a mean difference of (8.49) favoring females. The "T" value for the support from the family was (5.357) with a mean difference of (2.44), from colleagues and friends was (7.229) with a mean difference (3.42), and from university was (4.726) with a mean difference (2.63). All these differences favored the females. Moreover, no statistically significant differences between the males and females in the arithmetic means of assertiveness, as the value of " $t$ " was (1.870) with a mean difference of (0.61).

Table (8): The significance of the differences in social support and assertiveness according to the type of study

\begin{tabular}{|c|c|c|c|c|c|c|c|}
\hline Domains & Groups & No. & Means & SD & $\begin{array}{c}\text { Mean } \\
\text { difference }\end{array}$ & $\mathrm{T}$ & Sig \\
\hline \multirow{2}{*}{$\begin{array}{l}\text { Support from the } \\
\text { family }\end{array}$} & Scientific colleges & 62 & 34.40 & 3.82 & \multirow[t]{2}{*}{3.07} & \multirow[t]{2}{*}{5.080} & \multirow[t]{2}{*}{000} \\
\hline & Humanities colleges & 298 & 31.33 & 4.43 & & & \\
\hline \multirow{2}{*}{$\begin{array}{l}\text { Support from } \\
\text { colleagues and friends }\end{array}$} & Scientific colleges & 62 & 32.71 & 4.62 & \multirow[t]{2}{*}{2.54} & \multirow[t]{2}{*}{3.847} & \multirow[t]{2}{*}{.000} \\
\hline & Humanities colleges & 298 & 30.17 & 4.76 & & & \\
\hline \multirow{2}{*}{$\begin{array}{l}\text { Support from the } \\
\text { university }\end{array}$} & Scientific colleges & 62 & 36.58 & 6 & \multirow[t]{2}{*}{1.03} & \multirow[b]{2}{*}{1.360} & \multirow{2}{*}{.175} \\
\hline & Humanities colleges & 298 & 35.55 & 5.33 & & & \\
\hline \multirow{2}{*}{ Social support } & Scientific colleges & 62 & 103.69 & 11.66 & \multirow[t]{2}{*}{6.64} & \multirow[t]{2}{*}{3.832} & \multirow[t]{2}{*}{.000} \\
\hline & Humanities colleges & 298 & 97.05 & 12.56 & & & \\
\hline \multirow{2}{*}{ Assertiveness } & Scientific colleges & 62 & 16.81 & 3.2 & \multirow[t]{2}{*}{1.36} & \multirow[t]{2}{*}{3.087} & \multirow[t]{2}{*}{.002} \\
\hline & Humanities colleges & 298 & 15.45 & 3.15 & & & \\
\hline
\end{tabular}




\begin{tabular}{||cr|}
\hline The Egyptian Journal of Social Work (EJSW) https://ejsw.journals.ekb.eg/e \\
ISSN: $2356-9204$ & Vol 11, Issue.1, January2021 \\
\hline
\end{tabular}

Table (8) illustrates significant differences at the level of 0.01 in social support between students of scientific and humanities colleges with a " $t$ " value of $(3,832)$ and a mean difference of $(6.64)$. There were statistically significant differences at the level of 0.01 in support from the family with a "t" value of (5.080) and a mean difference of (3.07) and from colleagues and friends with a " $t$ " value of (3.847) and a mean difference of (2.54). Both of them favored the students of scientific colleges. There were no statistically significant differences in support from the university with a " $t$ " value of (1.360) and a mean difference of (1.03). Moreover, there were statistically significant differences at the level of 0.01 with a " $t$ " value of (3.087) and a mean difference of (1.36) in favor of the students of scientific colleges.

Table (9): The relationship between social support and assertiveness

\begin{tabular}{|l|c|c|c|c|c|}
\hline Domains & \multicolumn{5}{|l|}{ Assertiveness } \\
\cline { 2 - 6 } & Sampling & Males & Females & $\begin{array}{c}\text { Scientific } \\
\text { colleges }\end{array}$ & $\begin{array}{c}\text { Humanities } \\
\text { colleges }\end{array}$ \\
\hline $\begin{array}{l}\text { Support from the } \\
\text { family }\end{array}$ & $.359^{* *}$ & $.457^{* *}$ & $.173^{*}$ & $.261^{*}$ & $.335^{* *}$ \\
\hline $\begin{array}{l}\text { Support from } \\
\text { colleagues and } \\
\text { friends }\end{array}$ & $.292^{* *}$ & $.391^{* *}$ & .074 & .215 & $.276^{* *}$ \\
\hline $\begin{array}{l}\text { Support from the } \\
\text { university }\end{array}$ & $.178^{* *}$ & $.287^{* *}$ & -.053 & .232 & $.158^{* *}$ \\
\hline $\begin{array}{l}\text { Social support } \\
\text { Soch }\end{array}$ & $.316^{* *}$ & $.459^{* *}$ & .048 & $.290^{*}$ & $.295^{* *}$ \\
\hline $\begin{array}{l}* * \text { Statistically significant at the level of } 0.01 \\
\text { * Statistically significant at the level of } 0.5\end{array}$ \\
\hline
\end{tabular}

Table (9) shows a positive correlation between social support and its sub-domains at the level of 0.01 , and the value of the correlation between social support and assertiveness was (0.316). While the correlation between the support from the family and assertiveness was ranked first, and scored (0.359), the correlation between the support from colleagues and friends and assertiveness was ranked second and scored (0.292), and the correlation between the support from university and assertiveness was ranked third and scored (0.178). The correlation between social support and its sub-domains and assertiveness was affected by gender (males-females). The correlation value increased between the two variables in the male sample, and all correlation values were significant at the level of 0.01 . In contrast, no significant correlation was found between the two variables in the female sample except for a correlation at the level of 0.05 between assertiveness and support from the family with a 
The Egyptian Journal of Social Work (EJSW) https://ejsw.journals.ekb.eg/e ISSN: 2356-9204

Vol 11, Issue.1, January2021

correlation value of $(0.173)$. The correlational relationship was also affected by the type of study (scientific-humanities). The relationship was stronger at the level of 0.01 between social support and its subdomains and assertiveness among the students of humanities colleges. Among the students of scientific colleges, there was a correlation between assertiveness and social support and support from the family only at the level of 0.05 .

\section{Discussion}

The present study examined the relationship between social support and its domains (support from the family, support from colleagues and friends, and support from the university) and assertiveness among university students because they are very important in the work of the caseworker. The literature showed their significance as they relate to the positive traits of the personality and environments of the clients. Thus, the social worker tries to develop them to help the clients resolve and prevent personal problems, reduce stress, and achieve psychological and social adjustment. Moreover, their absence relates to many psychological and social disorders.

The study revealed that university students have a perception that social support is high. The social support from the family was ranked first. This result is consistent with the findings of Al-Tarawneh and Al-Subhiyin(2017). The support from colleagues and friends was ranked second and rated high. The support from the university was ranked third and rated moderate. In the Arab culture, university students generally enjoy respect, appreciation, and support because of their high educational level. Furthermore, there were statistically significant differences at the level of 0.01 between males and females in their perception of social support favoring females. This finding agrees with the emotional nature of females.

University students have a moderate level of assertiveness, indicating their need for various programs to develop this assertiveness and acquire its skills. This finding suggests the need for changing the cultural pattern of individual communities that gives a lower estimation of assertiveness and assertive persons. No statistically significant differences were found between males and females in assertiveness. This result agrees with the findings of Mokhaimar, Abu Obaid, and Al-Absi (2015) and Raishan (2008). It disagrees with the findings of Alotayan (2017) that males have higher assertiveness than females. In contrast, the dominant culture argues that assertiveness is a feature of the males only. There were statistically significant differences among the students of scientific 
and humanities colleges in assertiveness, favoring the students of scientific colleges. This result contrasted with Raishan (2008) that found that the difference in assertiveness favored the students of humanities.

The strength and significance of the relationship differed in social support and assertiveness among males and females. It was stronger and more significant among males. The relationship also differed between the sample of scientific and humanities colleges' students in favor of the students of humanities colleges, despite the differences in the social support and assertiveness of the two samples favoring the students of scientific colleges. The results generally support the positive relationship between social support and assertiveness among university students. They agree with the findings of Ali (2018) and Segal (2005) but disagree with the findings of Elliott et al. (1991).

\section{Recommendations}

- The services of psychological and social counseling and guidance provided to university students, especially those who need psychological and social support, should include examining the levels of perceived social support and assertiveness.

- Professional intervention programs should be developed and their effectiveness in enhancing the levels of social support and assertiveness among university students should be tested because they are important for the university and future lives of students.

- When developing professional intervention programs to enhance the level of assertiveness among university students, measuring the level of the perceived support from the family, friends, and colleagues should be considered.

- Students should be trained in the methods of getting social support on and off-campus and their right to practice assertiveness permanently.

- Further studies should examine the relationship between social support and assertiveness to the demographic features and other personality variables among university students.

- Researchers of direct practice are invited to carry out experimental studies on the Arab university environment for more control and modeling of the causal relationships between social support and assertiveness. 


\section{The Egyptian Journal of Social Work (EJSW) https://ejsw.journals.ekb.eg/e}

ISSN: 2356-9204

Vol 11, Issue.1, January2021

\section{Limitations}

The study is applied to a limited sample (360 participants) and similar in demographic and cultural characteristics. It recommends consolidating the examination of the relationship among various groups of demographic characteristics and representing various cultures to support the results of this study or reveal various associations with other variables that were not covered.

\section{References}

Abdel-Rahman, M. (1998). Mental health studies. Cairo: Dar Quba for Printing and Publishing.

Abo Elela, M. (2012). The constructional model of the relationships between hope, social support, coping strategies, and psychological compatibility among university students. Journal of the College of Education, 23(89), 101-165.

Ahmed, F. (2012). The relationship between parental treatment (acceptancerejection) as perceived by children and assertiveness on secondary education pupils: A field study on a sample of secondary education students in El Oued (M.A. thesis). University of Tizi Ouzou, Algeria.

Al-Ahmad, A. (2018). The relationship between parental treatment styles and assertiveness on a sample of Damascus University students. Association of Arab Universities Journal for Education and Psychology, 16(3), 15-44.

Al-Amoudi, Y. (2001). The relationship between marital compatibility, selfaffirmation, and relationship to some variables among married couples in Mecca (M.A. thesis). Umm Al-Qura University, Mecca.

Al-Dafai, H. (2011). The relationship between assertiveness and psychological and social computability of students of the Teacher Training Institute in Karbala (M.A. thesis). University of Kerbala, Karbala.

Ali, A. (2000). The relationship between social support, stressful life events, and compatibility with social life among university students living with their families or dormitory. Journal of Psychology, 14(53), 6-23.

Ali, B. (2018). The relationship between assertiveness and social support among kindergarten children. Journal of Arts, Literature, Humanities and Sociology, (20), 315-342.

Al-Issawi, M., Suleiman, S. \& Ibrahim, A. (2017). The relationship between social support, self-esteem, and academic achievement among university students. Journal of Scientific Research in Arts, 18(3), 361-383.

Al-Mahdawi, A. (2012). The meaning of life, social support, and relationship to some psychological disorders among the injured in traffic accidents in Saudi Arabia. Journal of Arab Studies in Education and Psychology, 1(31), 93-158.

Almajali, M. (2017). The effectiveness of an assertiveness training-based program in improving leadership skills among students of teamwork and activities. The International Interdisciplinary Journal of Education, 6 (11), 1-12.

Al-Musharraf, F. (2002). The relationship and differences in anxiety and religious and assertive behavior among a sample of female students at King Faisal University in Al-Ahsa, Saudi Arabia. Contemporary Education: The Modern Education Association, 19(61), 169-195.

Alotayan, T. (2017). The relation between self-affirmation and parental acceptance and rejection among the students of the preparatory year. Journal of Human and Social Sciences, (47)95-152. 


\section{The Egyptian Journal of Social Work (EJSW) https://ejsw.journals.ekb.eg/e}

ISSN: 2356-9204

Vol 11, Issue.1, January2021

Al-Sarsi, A. and Abdel-Maqsoud, A. (2014). Social support scale. Cairo: The Anglo-Egyptian Bookshop.

Al-Shahrani, A. (2012). Social support and self-affirmation among gifted and nongifted students in secondary school in Saudi Arabia and relationship to some demographic variables (M.A. thesis). Arabian Gulf University, Bahrain.

Al-Sharqawi, N. (2007). Towards a program to enable social work students to develop their assertiveness. Journal of Studies in Social Work and Humanities, 23(5), 2084-2115.

Al-Tarawneh, A. and Al-Subhiyin, A. (2015). Social support styles and its relationship with social responsibility among Mutah University students. Journal of Education, 1(162), 447-466.

Al-Tom, M. (2018). Attitudes of university students towards drug addiction and its relationship to social support: A descriptive study on the students of Qatar University and Omdurman Islamic University (M.A. thesis). Omdurman Islamic University, Sudan.

Akeren, İ., \& AY, İ. (2019). Üni $\square$ versi $\square$ te Öğrenci $\square$ leri $\square$ nde Algilanan Sosyal Destek Ve Güvengenli $\square$ k İle Psi $\square$ koloji $\square$ k Yardim Gereksi $\square$ ni $\square$ mleri $\square$ ni $\square$ n Incelenmesi $\square$. International Journal of Turkish Literature, Culture, Education, 8(2), 1222-1248.

Badari, A. and Al-Shennawi, M. (1987). The relationship between control, assertiveness, and problem-solving strategies. Researches and Studies in Social Sciences, 2, 219-265.

Bani Younes, M. (2005). The relationship between emotional stability and selfassertion levels on a sample of students at the University of Jordan. An-Najah University Journal for Research- Humanities, 19(3), 925-952.

Bashir, F. (2016). The effectiveness of a program for developing assertiveness in increasing self-efficacy, social competence, and academic performance among secondary school students in Gaza (Ph.D. dissertation). The Arab League's Educational, Cultural and Scientific Organization, Cairo.

Bayrami, M. (2011). Effect of assertiveness training on general health among firstyear students of the University of Tabriz. Psychological Research, 14(1), 47-64.

Baza, A. (2003). Assertiveness scale among adolescents and youth. Cairo: The Anglo-Egyptian Bookshop.

Daniel, A. (2008 a). Social support scale for $1^{\text {st }}$-secondary grade students. Cairo: The Anglo-Egyptian Bookshop.

Daniel, A. (2008 b). Social Support scale: Translation and domestication for the Arab environment. Cairo: The Anglo-Egyptian Bookshop.

De Miguelsanz, M., Martin, M. \& Martinez, M. (2012). Assertive skills and academic performance in primary and secondary education, giftedness, and conflictive students. Electronic Journal of Research in Educational Psychology, 10(1), 213-232.

Elliott, T., Herrick, S., Patti, A., Witty, T., Godshall, F. \& Spruell, M. (1991). Assertiveness, social support, and psychological adjustment following spinal cord injury. Behaviour Research and Therapy, 29(5), 485-493.

Eskin, M. (1995). Suicidal behavior as related to social support and assertiveness among swedish and Turkish high.. Journal of Clinical Psychology, 51(2), 158$172 . \quad$ https://doi-org.sdl.idm.oclc.org/10. $1002 / 1097-$ 4679(199503)51:2<158::AID-JCLP2270510204 >3.0.CO; 2-H 


\section{The Egyptian Journal of Social Work (EJSW) https://ejsw.journals.ekb.eg/e}

ISSN: 2356-9204

Vol 11, Issue.1, January2021

Farag, T. (2003). Social and economic skills. Cairo: Dar Gharib for Printing and Publishing.

Fayed, F. (2006). Social support as a mediating variable between life stress and perception of suicide. Journal of Studies in Social Work and Humanities, 21(2), 981-1020.

Gad, M. (2014). The relationship between parental treatment styles and assertiveness among middle school students (M.A. thesis). Helwan University, Egypt.

Ghareeb, A. (1995). Self-emphasis scale: The Emirati version. Cairo: The AngloEgyptian Bookshop.

Halasa, F. (2016). The effect of an assertiveness-based training program in raising the source of control and communication skills among schooled adolescents. Amman: From Ocean to Gulf for Publishing and Distribution.

Hammouda, H. \& Rasheed, M. (2011). The importance of social support in achieving social and psychological adjustment among unemployed youth. Journal of Human and Social Sciences, (2), 1-38.

Hussein, T. \& Hussein, S. (2006). Educational and psychological stress management strategies ( $1^{\text {st }}$ ed.). Amman: Dar Alfikr.

Hussein, A. and Abbas, M. (2014). The relationship between social support and academic achievement among $4^{\text {th }}$-grade students. Journal of Physical Education Sciences, 7(6), 114-124.

Ibrahim, A. (2001). Post-stress of psychological and emotional trauma: A multidomain behavioral approach. Kuwait: Social Development Office.

Ismail, A. (2010). Self-efficacy and social support as predictors of the quality of life among university students. Paper presented at the Fourth International Conference of Social Studies "Social Studies: Scientific Solutions of Social Issues", Kuwait University, Kuwait.

Ismail, B. (2004). Social Support scale for factory workers. Cairo. The AngloEgyptian Bookshop.

Khalil, N. (2014).The relationship between psychological stress, assertiveness, and quality of life among international students in Islamic missions institutes. Journal of Childhood Studies, 17(64), 29-43.

Kukulu, K., Bulduloglu, K., Kulakac, O. \& Koksal, C. (2006). The effects of locus of control, communication skills and social support on assertiveness in female nursing students. Social Behavior and Personality: An International Journal, 34(1), 27-40. https://doi-org.sdl.idm.oclc.org/10.2224/sbp.2006.34.1.27.

Kwassa, I. and Muhammad, M. (2000). The relationship between assertiveness and parental acceptance/rejection. Journal of Education, 95(2), 307-339.

Lashari, S. A., Kaur, A., \& Awang-Hashim, R. (2018). Home Away from Home-The Role of Social Support for International Students' Adjustment. Malaysian Journal of Learning and Instruction, 15(2), 33-54.

Lee, J., \& Ciftci, A. (2014). Asian international students' socio-cultural adaptation: Influence of multicultural personality, assertiveness, academic self-efficacy, and social support. International Journal of Intercultural Relations, 38, 97-105. https://doi-org.sdl.idm.oclc.org/10.1016/j.ijintrel.2013.08.009

Mokhaimar, S., Abu Obaid, D. \& Al-Absi, S. (2015). Social intelligence, selfaffirmation, and relationship to speaking anxiety among students of practical education. The University of Palestine Journal, (8), 346-376. 


\begin{tabular}{||cr||}
\hline The Egyptian Journal of Social Work (EJSW) https://ejsw.journals.ekb.eg/e \\
ISSN: $2356-9204$ & Vol 11, Issue.1, January2021 \\
\hline \hline
\end{tabular}

Monti, P. (2002). Treating alcohol dependence: A coping skills training guide. New York: The Guilford Press.

Muhammad, R. (2003). Assertiveness training and relationship to some personality traits among university students. Journal of Psychological Counseling, (17), $155-215$.

Najjar, N. and Abo Darweesh, M. (2011). The relationship between social support, self-esteem, loneliness, academic achievement, study level, and gender among students of the College of Educational Sciences at Mutah University. Mutah for Research and Studies, 26(1), 257-292.

Parmaksiz, I. (2019). Assertiveness as the Predictor of Adjustment to University Life amongst University Students. International Journal of Instruction, 12(4), 131-148.

Raishan, H. (2008). Measuring the skill of self-affirmation among students of the college of education. Journal of Education College for Girls for Humanistic Sciences, 2(3), 167-180.

Rashwan, A. (2007). Professional intervention using solution-centered therapy to achieve social support among university students. Paper presented at the Twentieth International Conference of Social Work, Helwan University, Egypt.

Saleh, H. (2009). Social support and its effects on the quality of life for diabetics: A psychometric study (M.A. thesis). Zagazig University, Egypt.

Segal, D. (2005). Relationships of assertiveness, depression, and social support among older nursing home residents. Behavior Modification, 29(4), 689-695. 
The Egyptian Journal of Social Work (EJSW) https://ejsw.journals.ekb.eg/e ISSN: 2356-9204 Vol 11, Issue.1, January2021 